\title{
ДИНАМІКА ЗМІН ЖИВОЇ МАСИ ТА ОСОБЛИВОСТІ РОСТУ ТА РОЗВИТКУ МОЛОДНЯКУ СВИНЕЙ РІЗНОГО ПОХОДЖЕННЯ
}

\section{К. Гарматюк, Р. Сусол, І. Ткаченко}

Одеський державний аграрний університет

Одержані результати засвідчують, що запропоноване виробництво фінальних гібридів з умовною часткою крові 3/4 ландраса + 1/4 великої білої за показником живої маси є найбільш вдалим та адаптованим до технології помірного рівня інтенсивності. Використання чистопородних та помісних тварин, ще мають відношення до так званих «білих порід» - велика біла та ландрас, відзначається підвищеними показниками інтенсивності формування та індексів напруги росту. Одержані результати додатково підтверджують складність адаптаиії кольорових порід (дюрок та особливо породи п'єтрен) до технологічних умов вітчизняних господарств з виробництва свинини. Молодняк свиней одержаний у поєднаннях, де батьківською формою були породи: велика біла, ландрас або дюрок відзначався кращими екстер'єрними особливостями, щзо характеризують розвиток тварин у довжину. $У$ поєднаннях, де батьківською формою була порода п'єтрен покращувалися широтні проміри та індекс м'ясності на фоні зменшення довжини тулубу.

Ключові слова: гібридний молодняк, жива маса, ріст, розвиток, екстер'єр, адаптаиія.

Постановка проблеми. Використання у процесі селекції генотипів тварин та свиней зокрема із високою інтенсивністю їх росту потребує вивчення закономірностей формоутворюючих процесів у різні періоди онтогенезу індивідуумів й визначення їх впливу на племінну цінність тварин. Крім того, інтенсивність росту відіграє ключову роль у товарному свинарстві та забезпечує економічну доцільність виробництва продукції. Інтенсивність формування молодняку на початковому етапі онтогенезу визначається спадковістю та умовами утримання, що в свою чергу обумовлюється продуктивністю повновікових тварин. На думку автора даної теорії Ю. К. Свєчина, інтенсивність формування знаходиться у тісному зв'язку зі скороспілістю, тобто $є$ її першопричиною [7].

Аналіз останніх досліджень i публікацій. Експериментальними дослідженнями багатьох вчених $[2,4,5,8,10]$ доведено, що молодняк свиней сучасних порід різного напрямку продуктивності, а також помісні тварини у процесі контрольної відгодівлі та вирощування мають різноманітний діапазон скоростиглості та оплати корму.

Метою досліджень було вивчити динаміку змін живої маси та особливості росту, розвитку молодняку свиней різного походження в умовах півдня України. 
Матеріал і методи дослідження. Наукові дослідження проводили у період iз 2016 по 2018 pр. в умовах ТОВ «Агрофірми «Шаболат» БілгородДністровсього району Одеської області, а також на базі кафедри технології виробництва i переробки продукції тваринництва Одеського державного аграрного університету. Сформували контрольну та 6 дослідних груп тварин за загальноприйнятими методиками [9] аналогів 3 урахуванням їх віку, фізіологічного стану та розвитку. Загальна схема науково-господарського досліду наведена у таблиці 1.

Таблиця 1.Схема науково-господарського досліду.

\begin{tabular}{|c|c|c|c|c|}
\hline \multirow[t]{3}{*}{ Група } & \multicolumn{2}{|c|}{ Батьківські форми } & \multirow{2}{*}{$\begin{array}{c}\text { Відгодівельний молодняк } \\
(\mathbf{n = 2 0}),\end{array}$} & \multirow[t]{2}{*}{ Враховані показники: } \\
\hline & свиноматки $(\mathrm{n}=10)$ & кнури $(n=3)$ & & \\
\hline & Генотип & генотип & генотип & \multirow{8}{*}{$\begin{array}{l}\text {-морфологічний } \\
\text { склад туші; } \\
\text {-фізико-хімічні } \\
\text { характеристики } \\
\text { м'яса та сала; } \\
\text { - хімічний склад } \\
\text { м’язової тканини } \\
\text {-дегустаційна оцінка } \\
\text { вареного м'яса та } \\
\text { бульйону }\end{array}$} \\
\hline I контрольна & велика біла & велика біла & велика біла & \\
\hline II дослідна & велика біла & ландрас & 1/2 (велика біла + ландрас) & \\
\hline III дослідна & $\mathrm{F}_{1} *$ & велика біла** & 3/4 велика біла + 1/4 ландрас & \\
\hline IV дослідна & $F_{1}$ & $\mathrm{~F}_{1}$ & 1/2 (велика біла + ландрас) & \\
\hline V дослідна & $\mathrm{F}_{1}$ & ландрас** & 3/4 ландрас + 1/4 велика біла & \\
\hline VI дослідна & $\mathrm{F}_{1}$ & п’єтрен & $\begin{array}{c}\text { 1/4 велика біла }+1 / 4 \text { ландрас }+1 / 2 \\
\text { п'єтрен }\end{array}$ & \\
\hline VII дослідна & $\mathrm{F}_{1}$ & $\begin{array}{l}\text { 1/2 (п’етрен } \\
+ \text { дюрок) }\end{array}$ & $\begin{array}{c}1 / 4 \text { велика біла }+1 / 4 \text { ландрас }+ \\
1 / 4 \text { п’єтрен }+1 / 4 \text { дюрок }\end{array}$ & \\
\hline
\end{tabular}

Примітка: * - $\mathrm{F}_{1}-$ помісні свиноматки та кнури 1/2 (велика біла + ландрас); ** - спеціалізована батьківська форма відповідної породи.

Оцінку показників росту та розвитку піддослідного молодняку різних генотипів проводили з урахуванням живої маси в 0, 1, 2, 3, 4, 6 і 8 місяців та їх абсолютних, середньодобових та відносних приростів.

По закінченні відгодівлі у піддослідних свиней було взято проміри тулубу (обхват грудей, обхват заду, висота в холці, ширина грудей, глибина грудей, ширина і глибина попереку, напівобхват заду), визначали індекси тілобудови.

Ріст тварин оцінювали за результатами індивідуальних зважувань. Поряд 3 цим були розраховані показники інтенсивності росту тварин за формулами:

\section{Інтенсивність формування -}

$$
\begin{aligned}
& \Delta \mathrm{t}=\underline{\mathrm{M}}_{4}-\underline{\mathrm{M}}_{2}-\underline{\mathrm{M}}_{6}-\underline{\mathrm{M}}_{4} \\
& 0,5\left(\mathrm{M}_{4}+\mathrm{M}_{2}\right) 0,5\left(\mathrm{M}_{6}+\mathrm{M}_{4}\right)
\end{aligned}
$$

$$
\mathrm{Ip}=\frac{1}{1+\Delta \mathrm{t}} \times \mathrm{C \Pi}
$$

\section{Індекс рівномірності росту —}

де: СП - середньодобовий приріст тварин за період від 2-ох до 6-місячного віку, кг

$$
\mathrm{IH}=\underline{\Delta \mathrm{t}} \times \mathrm{C \Pi}
$$

\section{Індекс напруги росту -}

\section{ВП}

де: ВП - відносний приріст тварин за період від народження від 2-ох до 6місячного віку, кг

$\mathrm{M}_{2}, \mathrm{M}_{4}$ і $\mathrm{M}_{6}$, відповідно жива маса тварин у віці 2, 4 і 6 місяців.

Результати досліджень оброблені за допомогою статистичних методів. 
Розрахунки проводили за допомогою ПК, в програмі MS Excel 2010.

Визначення біометричних та кореляційних показників проводили за методиками Н. А. Плохинского [6], Коваленка В. П. та ін. [3] і Крамаренка С. С. та ін. [1]. Результати дослідження. Динаміка змін живої маси молодняку наведена у таблиці 2, аналіз даних якої доводить у віці 2 місяців молодняк усіх дослідних груп складного походження переважав ровесників контрольної групи великої білої породи на 0,1-1,6 кг або на 0,6-9,4\%. Причому, найменша ця різниця встановлена у молодняку III дослідної групи (різниця між групами практично відсутня), помірно виражена різниця у молодняку II, IV дослідних груп (відповідно на $3,5 \%$ та 2,9\%), а найбільш яскраво та достовірно (при $\mathrm{P} \geq 0,99-0,999)$ виражена різниця за живою масою у молодняку V, VI, VII дослідних груп (відповідно на 6,4\%, 8,2\% та 9,4\%).

Таблиця 2.Динаміка змін живої маси молодняку, $(\mathrm{n}=20)$

\begin{tabular}{|c|c|c|c|c|c|c|}
\hline \multirow{3}{*}{$\begin{array}{l}\text { Група } \\
\text { тварин }\end{array}$} & & \multicolumn{5}{|c|}{ Вік, міс. } \\
\hline & & 2 & 3 & 4 & 5 & 6 \\
\hline & & \multicolumn{5}{|c|}{ Жива маса, кг } \\
\hline I & $\overline{\bar{X}} \pm S_{\bar{X}}$ & $17,1 \pm 0,22$ & $32,4 \pm 0,46$ & $51,7 \pm 0,71$ & $74,0 \pm 0,94$ & $96,9 \pm 1,16$ \\
\hline II & $\bar{X} \pm S_{\bar{X}}$ & $17,7 \pm 0,24$ & $33,0 \pm 0,51$ & $52,3 \pm 0,83$ & $74,9 \pm 1,02$ & $100,6 \pm 1,15^{*}$ \\
\hline III & $\bar{X} \pm S_{\bar{X}}$ & $17,2 \pm 0,20$ & $32,6 \pm 0,40$ & $53,0 \pm 0,60$ & $76,3 \pm 0,90$ & $101,9 \pm 1,10^{* *}$ \\
\hline IV & $\bar{X} \pm S_{\bar{X}}$ & $17,6 \pm 0,34$ & $32,9 \pm 0,74$ & $52,6 \pm 1,76$ & $75,7 \pm 2,10$ & $101,3 \pm 2,42$ \\
\hline $\mathrm{V}$ & $\bar{X} \pm S_{\bar{X}}$ & $\begin{array}{c}18,2 \pm 0,20 \\
* * *\end{array}$ & $\begin{array}{c}34,7 \pm 0,43 \\
* * *\end{array}$ & $\begin{array}{c}55,4 \pm 0,65 \\
* * *\end{array}$ & $\begin{array}{c}80,1 \pm 0,91 \\
* * *\end{array}$ & $\begin{array}{c}110,1 \pm 1,28 \\
* * *\end{array}$ \\
\hline VI & $\overline{\bar{X}} \pm S_{\bar{X}}$ & $\begin{array}{c}18,5 \pm 0,37 \\
* *\end{array}$ & $\begin{array}{c}29,8 \pm 0,58 \\
* * *\end{array}$ & $\begin{array}{c}48,9 \pm 0,98 \\
*\end{array}$ & $71,4 \pm 1,20$ & $98,9 \pm 1,41$ \\
\hline VII & $\bar{X} \pm S_{\bar{X}}$ & $\begin{array}{c}18,7 \pm 0,39 \\
* * *\end{array}$ & $\begin{array}{c}30,4 \pm 0,60 \\
* *\end{array}$ & $52,0 \pm 0,82$ & $74,8 \pm 0,92$ & $99,2 \pm 1,12$ \\
\hline
\end{tabular}

У подальші вікові періоди (3-, 4-, 5-, 6-ти місяців) помірний рівень переваги за показниками живої маси дослідних груп порівняно з контрольною групою спостерігався у тварин II, III, IV дослідних груп. Причому у віці 3-5 місяців встановлена лише тенденція до переваги, оскільки різниця статистично невірогідна, а у віці 6-ти місяців молодняк II дослідної групи за живою масою переважав ровесників контрольної на 3,7 кг або на 3,8\% при $\mathrm{P} \geq 0,95$. Молодняк III дослідної групи у віці 6-ти місяців за живою масою переважав ровесників контрольної вже на 5,0 кг або на 5,2\% при $\mathrm{P} \geq 0,99$. Молодняк IV дослідної групи у віці 6-ти місяців за живою масою також переважав ровесників контрольної на 4,7 кг або на 4,5\%, проте через підвищені показники мінливості $(\mathrm{Cv}=8,73-14,96 \%$ у різні вікові періоди) порівняно з іншими групами різниця між контролем статистично невірогідна, що говорить про нестабільність прояву ефекту гетерозису та в цілому невдалий варіант даного комбінаційного поєднання, який небажано використовувати у подальшому в умовах виробництва.Найкращі показники живої маси молодняку у різні вікові періоди, що одержані за результатами проведеного нами експерименту виявлено у 
тварин V дослідної групи. Так, молодняк цієї групи переважав ровесників контрольної групи віці 2-, 3-, 4-, 5-, 6-ти місяців відповідно на 1,1 кг, 2,3 кг, 3,7 кг, 6,1 кг та 13,2 кг або відповідно на 6,43\%, 7,10\%, 7,2\%, 8,2\% та 13,6\%. Одержані результати засвідчують, що запропоноване нами поєднання порід 3 метою одержання фінального гібрида 3 умовною часткою крові $3 / 4$ ландраса $+1 / 4$ великої білої за показником живої маси $\epsilon$ найбільш вдалим. Такий генотип (порода ландрас) є найбільш адаптованим до технології помірного рівня інтенсивності (годівля різних вікових груп молодняку свиней комбікормами, де основним джерелом протеїну $є$ соняшниковий шрот, утримання тварин у приміщеннях 3 нерегульованим штучно мікрокліматом). Підтвердженням вищевикладеного є одержані результати за показниками живої маси у різні вікові періоди у молодняку VI дослідної групи, тварини якої у 2-ох місячному віці переважали ровесників контрольної групи за рахунок прояву ефекту гетерозису на 1,4 кг або на 8,2\% (Р $\geq 0,99)$, проте вже у віці 3-, 4-, 5-ти місяців, навпаки, поступалися чистопородному молодняку ВБ породи відповідно на 2,6 кг (P $\geq 0,999), 2,8$ кг ( $\mathrm{P} \geq 0,95), 2,6$ кг або на 8,0\%, 5,42\%, 3,51\%. Достатньо цікавим виявився факт, що у 6-ти місячному віці знову виявлено ефект гетерозису. Так, молодняк VI дослідної групи у цьому віці переважав ровесників контрольної групи за рахунок прояву ефекту гетерозису на 2,0 кг або на 2,1\%. Одержані результати доводять, що для прояву ефекту гетерозису для високопродуктивних генотипів є потреба у специфічних умовах годівлі та утримання. На нашу думку, порода п’єтрен має підвищені потреби до протеїнового живлення, температурного, вологістного режимів, комфорту утримання тощо порівняно з породою ландрас як більш адаптованого та менш вибагливого генотипу. Саме цим можна пояснити різке зменшення живої маси молодняку VI дослідної групи порівняно з ровесниками контрольної групи у віці 3-місяців (у період 32 до 3-ох місяців відбувається перехід на годівлю молодняку 100\% рослинними інгредієнтами). Зі збільшенням віку різниця за живою масою між молодняком VI дослідної групи порівняно з ровесниками контрольної групи нівелюється, що простежується у динаміці зменшення переваги тварин контрольної групи за живою масою з 8,0\% у віці 3-ох місяців до 3,51\% у віці 5-ти місяців, а у віці 6-ти місяців тенденція до переваги вже на боці молодняку VI дослідної групи. Тобто, чим старше стає молодняк VI дослідної групи, що містить 50\% умовної частки крові породи п’єтрен, потреба у протеїновому живленні та підвищеному комфорті утримання поросят зменшується, що дозволяє проявитися знову ефекту гетерозису. Використання в якості фінального гібриду молодняку VII дослідної групи, що містить по 25\% умовної частки крові порід велика біла, ландрас, п’єтрен та дюрок нівелює підвищену вибагливість породи п’етрен до факторів годівлі та утримання, що знаходить підтвердження в тому, що тварини VII дослідної групи у 3-ох місячному віці поступаються ровесникам контрольної групи на 2,0 кг або на 6,2\%, а у 4-, 5- та у 6-ти місячному віці мають тенденцію до переваги на 0,3 кг, 0,8 кг та 2,3 кг або відповідно на 0,6\%, 1,1\% та 2,4\%. Слід відзначити, що молодняк VII дослідної групи у 2-ох місячному віці мав найбільшу перевагу за показником живої маси над ровесникам контрольної групи на 1,6 кг або на 9,4\% 
при $\mathrm{P} \geq 0,999$, що свідчить про перспективність даного поєднання (1/4 велика біла $+1 / 4$ ландрас $+1 / 4$ п'єтрен $+1 / 4$ дюрок) за умови створення спеціальної породної технології, що адаптована до місцевих кліматичних та технологічних умов вітчизняних свинарських підприємств. Механізм різниці у живій масі молодняку свиней різних генотипів піддослідних груп розкривається через аналіз динаміки середньодобового (табл. 3).

Таблиця 3.Динаміка середньодобового приросту молодняку $(\mathrm{n}=20)$

\begin{tabular}{|l|c|c|c|c|l|}
\hline \multirow{2}{*}{ Група } & \multicolumn{5}{|c|}{ Віковий період, міс. } \\
\cline { 2 - 6 } & $\mathbf{2 - 3}$ & $\mathbf{3 - 4}$ & $\mathbf{4 - 5}$ & $\mathbf{5 - 6}$ & \multicolumn{2}{|c|}{$\mathbf{2 - 6}$} \\
\cline { 2 - 6 } & \multicolumn{5}{|c|}{ Середньодобовий приріст, г } \\
\hline I & $510,5 \pm 6,64$ & $640,2 \pm 9,19$ & $743,1 \pm 10,24$ & $763,0 \pm 9,75$ & $665,0 \pm 7,94$ \\
\hline II & $512,0 \pm 6,90$ & $645,4 \pm 10,02$ & $753,4 \pm 11,93$ & $856,7 \pm 12,23$ & $690,8 \pm 8,89$ \\
\hline III & $513,2 \pm 5,83$ & $680,0 \pm 8,28$ & $776,7 \pm 8,79$ & $853,5 \pm 10,08$ & $705,8 \pm 8,51$ \\
\hline IV & $510,6 \pm 9,96$ & $656,7 \pm 14,81$ & $770,0 \pm 25,77$ & $850,2 \pm 23,62$ & $697,5 \pm 14,67$ \\
\hline V & $550,0 \pm 6,13$ & $690,0 \pm 8,48$ & $823,5 \pm 9,69$ & $1000,7 \pm 11,37$ & $765,8 \pm 9,94$ \\
\hline VI & $376,7 \pm 7,56$ & $636,7 \pm 12,45$ & $750,0 \pm 15,13$ & $916,7 \pm 15,46$ & $670,0 \pm 10,61$ \\
\hline VII & $390,1 \pm 8,09$ & $720,0 \pm 14,30$ & $760,1 \pm 12,00$ & $813,1 \pm 9,95$ & $670,8 \pm 8,57$ \\
\hline
\end{tabular}

Так, у період 3 2-ох до 3-ох місяців підвищений середньодобовий та відносний прирости були встановлені у молодняку V дослідної групи відповідно 550 г. Найменший рівень приростів мали поросята VI дослідної групи - 377 г. Інші враховані вікові періоди (3-4 міс.; 4-5 міс.; 5-6 міс) характеризуються достатньо інтенсивним ростом молодняку свиней усіх піддослідних груп. Виявлена наступна закономірність: відносно однакові та помірні показники середньодобових приростів виявлені у молодняку свиней I контрольної, II, IV дослідних груп. Підвищеними дані показники були у молодняку свиней III, V дослідних груп. Виявлено специфічність впливу ультрам'ясних генотипів (батьківських форм) на середньодобовий прирости нащадків VI, VII дослідних груп, які відзначалися зниженими даними показниками до 4-ти місячного віку, а 3 5-ти місячного віку навпаки середньодобові прирости у даних генотипів суттєво зростав. Одержані результати, на нашу думку, доводять певну специфічність росту нащадків одержаних від ультрам'ясних генотипів (порід) свиней з умовною часткою крові тварин VI дослідної групи 1/4 велика біла + 1/4 ландрас + 1/2 п'єтрен та VII дослідної групи 1/4 велика біла $+1 / 4$ ландрас $+1 / 4$ п'єтрен $+1 / 4$ дюрок $1 / 4$ велика біла $+1 / 4$ ландрас + 1/4 п'єтрен + 1/4 дюрок, генетичний потенціал яких не повністю розкрито через їх підвищену потребу до енергетичного, протеїнового та вітамінно-мінерального живлення у період після відлучення від матерів та зокрема 32 до 4 місяців порівняно 3 «білими породами» типу великої білої та 
ландрас. В одержаних результатах можна вбачати адаптаційні механізми на користь молодняку свиней «білих порід» до технологічних умов вітчизняних господарств, що додатково пояснює низку переваг V дослідної групи. Більш об'єктивне уявлення про ріст молодняку дають показники інтенсивності росту, a саме: інтенсивність формування, індекси рівномірності і напруги росту. За показником інтенсивності формування молодняк I контрольної групи переважав аналогів II-VII дослідних груп на 2,24-43,27\%. Так, молодняк III дослідної групи за даним показником наближався до рівня I контрольної групи (відповідно 0,389 та 0,397), тобто поступався лише на 2,24\%, а молодняк VII дослідної групи суттєво поступався - на 43,27\% (табл. 4).

Таблиця 4. Показники інтенсивності росту

\begin{tabular}{|c|c|c|c|}
\hline \multirow{2}{*}{$\begin{array}{c}\text { Піддос- } \\
\text { лідні } \\
\text { групи }\end{array}$} & \multirow{2}{*}{$\begin{array}{c}\text { Інтенсивність } \\
\text { формування }\end{array}$} & $\begin{array}{c}\text { Рівномірності } \\
\text { росту }\end{array}$ & напруги росту \\
\hline I(к) & 0,397 & 0,476 & 0,189 \\
\hline II & 0,357 & 0,509 & 0,176 \\
\hline III & 0,389 & 0,508 & 0,192 \\
\hline IV & 0,364 & 0,511 & 0,180 \\
\hline V & 0,350 & 0,567 & 0,187 \\
\hline VI & 0,225 & 0,547 & 0,110 \\
\hline VII & 0,318 & 0,509 & 0,156 \\
\hline
\end{tabular}

Аналіз індексу рівномірності росту свідчить про те, що молодняк II та III дослідних груп росли більш рівномірно і мали переваги за даним показником на $7,00 \%$ та 8,82\% порівняно 3 ровесниками контрольної групи. Піддослідні тварини IV-VII групи за показником рівномірності росту знаходилися на одному рівні та практично відповідали аналогічним показникам тварин контрольної групи. Варто зауважити, що дещо підвищеною напругою росту характеризувався молодняк свиней III дослідної групи, який переважав за даним показником молодняк I контрольної групи на 1,59\%. Тварини II, IV та V дослідних груп мали нижчий індекс напруги росту порівняно з аналогами I контрольної групи відповідно на 6,88\%, 4,76\% i 1,06\%. Суттєво меншим значенням даного індексу відрізнявся молодняк свиней VI та VII дослідних груп, що на $41,80 \%$ та $17,46 \%$ менше, ніж молодняк I контрольної групи. Співставлення індексів дає можливість судити не тільки про формування їх росту і розвитку в окремі періоди життя, а й виявити індивідуальні особливості більш бажаного типу, тому на основі промірів піддослідних тварин нами було вирахувано індекси їх тілобудови (табл. 5). 
Таблиця 5. Індекси тілобудови молодняку свиней різного походження за живої маси 100 кг, \%

\begin{tabular}{|c|c|c|c|c|c|c|c|c|}
\hline \multirow[b]{2}{*}{ 吾 } & \multicolumn{8}{|c|}{ Індекси тілобудови, \% } \\
\hline & $\begin{array}{l}\text { розтяг- } \\
\text { нутості }\end{array}$ & $\begin{array}{l}\text { компак } \\
\text { T- } \\
\text { ності }\end{array}$ & $\begin{array}{l}\text { масив- } \\
\text { ності }\end{array}$ & $\begin{array}{l}\text { шитроко } \\
\text { - } \\
\text { грудості }\end{array}$ & $\begin{array}{l}\text { глибоко } \\
\text { - } \\
\text { грудості }\end{array}$ & $\begin{array}{l}\text { костис } \\
- \\
\text { тості }\end{array}$ & м'ясності & $\mathbf{I}^{\prime} \mathbf{B}^{1}$ \\
\hline I (К) & 173,50 & 88,72 & 153,93 & 74,49 & 53,16 & 23,57 & 106,01 & 112,6 \\
\hline II & 177,23 & 89,24 & 158,15 & 80,23 & 52,92 & 24,46 & 110,61 & 115,2 \\
\hline III & 176,61 & 89,18 & 157,49 & 79,32 & 53,98 & 24,46 & 111,01 & 115,5 \\
\hline IV & 173,94 & 90,07 & 156,67 & 79,71 & 53,03 & 23,94 & 109,24 & 114,8 \\
\hline $\mathrm{V}$ & 177,96 & 89,07 & 158,51 & 78,71 & 54,26 & 25,23 & 113,07 & 117,1 \\
\hline VI & 175,32 & 94,22 & 165,19 & 79,40 & 57,59 & 26,58 & 124,84 & 110,8 \\
\hline VII & 177,32 & 89,79 & 159,21 & 77,01 & 54,95 & 25,88 & 115,68 & 116,5 \\
\hline
\end{tabular}

Примітка: 1 - ІДВ - індекс відношення довжини до ваги

Варто окремо зупинитися на індексі м'ясності. Так, тварини (рис. 1) усіх дослідних груп без винятку в цілому переважали аналогів контрольної групи на $3,24-18,84 \%$ за даним індексом.

\section{Індекс м'ясності, \%}

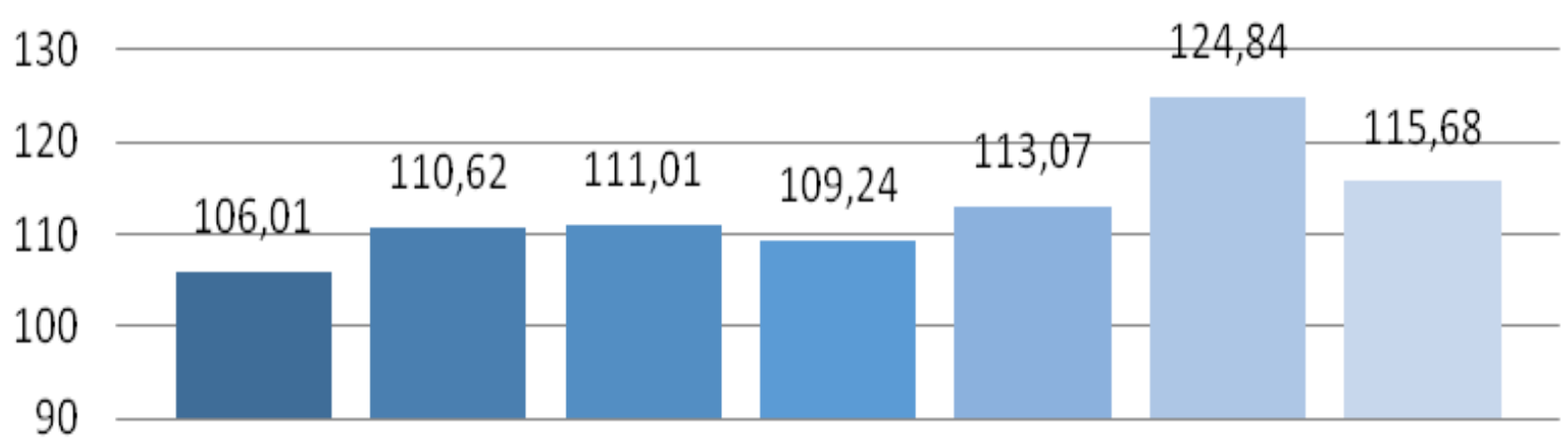

Категория 1

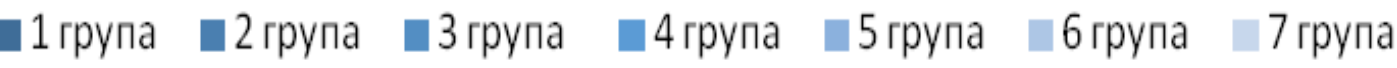

Рис. 1. Індекс м’ясності у піддослідних груп за живої маси 100 кг, \%.

Висновки: 1. Одержані результати засвідчують, що запропоноване нами поєднання порід з метою одержання фінального гібрида 3 умовною часткою крові $3 / 4$ ландраса $+1 / 4$ великої білої за показником живої маси $\epsilon$ найбільш 
вдалим та адаптованим до технології помірного рівня інтенсивності. 2. Використання чистопородних та помісних тварин, що мають відношення до так званих «білих порід» - велика біла та ландрас, відзначається підвищеними показниками інтенсивності формування та індексів напруги росту. При цьому індекс рівномірності росту інтенсивності росту у молодняку II-IV дослідних груп є помірним та за абсолютними показниками наближається один до одного. Найвищий рівень індексу рівномірності росту характерний для тварин V дослідної групи. Стосовно гібридного молодняку VI дослідної групи, де батьківською формою є п’єтрен, варто зазначити, що встановлено найнижчий показник інтенсивності формування (0,225), підвищений показник індексу рівномірності росту $(0,547)$ та найнижчий індекс напруги росту $(0,110)$. Одержані результати додатково підтверджують складність адаптації кольорових порід (дюрок та особливо породи п’єтрен) до технологічних умов вітчизняних господарств 3 виробництва свинини. 3.Молодняк свиней одержаний у поєднаннях, де батьківською формою були породи: велика біла, ландрас або дюрок відзначався кращими екстер'єрними особливостями, що характеризують розвиток тварин у довжину. У поєднаннях, де батьківською формою була порода п’єтрен покращувалися широтні проміри та індекс м’ясності на фоні зменшення довжини тулубу.

\section{ЛІТЕРАТУРА}

1. Аналіз біометричних даних у розведенні та селекції тварин : навчальний посібник / С. С. Крамаренко, С. І. Луговий, А. В. Лихач, С. С. Крамаренко - Миколаїв: МНАУ, 2019. - 211 с.

2. Березовський М. Д., Ващенко П. А. Варіанти поєднань різних генотипів свиней в системі гібридизації // Свинарство : міжвідомчий тематичний науковий збірник. Полтава, 2015. Вип. 67. С. 38-43.

3. Біометричний аналіз мінливості ознак сільськогосподарських тварин i птиці : навчальний посібник / В. П. Коваленко, В. І. Халак, Т. І. Нежлукченко, Н. С. Папакіна - Херсон: Олді-плюс, 2010. 225 с.

4. Гришина Л. П., Фесенко О.Г. Ефективність використання спеціалізованого типу свиней за схрещування та гібридизації // Вісник аграрної науки Причорномор'я. 2015. Вип. 2 (84). Т. 2. С. 40-47.

5. Онищенко А. О. Промислове схрещування i гібридизація, їх ефективність у свинарстві // Свинарство : міжвідомчий тематичний науковий збірник Інституту свинарства і АПВ НААН. Полтава, 2013. Вип. 62. С. 72-76.

6. Плохинский Н. А. Руководство по биометрии для зоотехников. М. : Колос, 1969. 256 с.

7. Свинарство : монографія / за наук. ред. В. М. Волощука. К. : Аграр. Наука, 2014. 592 с.

8. Сусол Р. Л., Гарматюк К. В., Халак В. І. Оптимізація системи розведення і годівлі свиней м'ясного напрямку продуктивності в умовах півдня України // Зернові культури. Дніпро, 2018. Т.2. № 12. С. 353-359.

9. Сучасні методики досліджень у свинарстві / В.П. Рибалко, М.Д. Березовський, Г.А. Богданов [та ін.]. Полтава: IC УААН, 2005. 228 с. 
10. Церенюк О. М. Комбінаційна здатність основних родин уельської породи свиней. // Таврійський науковий вісник. Херсон, 2007. Вип. 53. С. 122133.

\title{
ДИНАМИКА ИЗМЕНЕНИЙ ЖИВОЙ МАССЫ И ОСОБЕННОСТИ РОСТА И РАЗВИТИЯ МОЛОДНЯКА СВИНЕЙ РАЗЛИЧНОГО ПРОИСХОЖДЕНИЯ
}

\author{
Гарматюк К., Сусол Р. Ткаченко И.
}

Полученные результаты свидетельствуют, что предложенное производство финальных гибридов с условной долей крови 3/4 ландраса + 1/4 крупной белой по живой массе является наиболее удачным и адаптированным $\kappa$ технологии умеренного уровня интенсивности. Использование чистопородных $u$ помесных животных, имеюшчи отношение $\kappa$ так называемым «бельм породам» - крупная белая и ландрас, отмечается повышенными показателями интенсивности формирования и индексов напряженнности роста. Полученные результать дополнительно подтверждают сложность адаптации цзветных пород (дюрок и особенно породы пьетрен) к технологическим условиям отечественных хозяйств по производству свинины. Молодняк свиней полученный в сочетаниях, где отиовской формой были породы: крупная белая, ландрас или дюрок отличался лучшими экстерьерными особенностями, характеризующие развитие жсивотных в длину. В сочетаниях, где отцуовской формой была порода пьетрен улучшались широтные промеры и индекс мясности на фоне уменьшения длинь туловищьа.

Ключевые слова: гибридный молодняк, живая масса, рост, развитие, экстерьер, адаптація.

\section{THE DYNAMICS OF LIVE WEIGHT CHANGE AND SPECIFIC GROWTH PATTERN OF YOUNG PIG STOCK OF DIFFERENT BREED-OF-ORIGIN}

\author{
K. Garmatyuk, R. Susol, I. Tkachenko
}

The findings of this study show that the suggested production of the resulting hybrids with $3 / 4$ of Landrace $+1 / 4$ of Large White genes with regard to live weight is the best choice and most suitable option for moderately intensive swine production systems. The use of purebred and crossbred pigs related to the so-called "white breeds" - namely, Large White and Landrace - has been marked by higher formation and growth rates. The results obtained additionally prove that it is quite challenging to adapt coloured swine breeds (such as Duroc and especially Pietrain) to the specific conditions of domestic pork farms. Young stock of crossbreds resulted from different combinations with Large White, Landrace or Duroc breeds used as paternal lines can be distinguished by better conformation traits specifying the body length dynamics. The offspring from combinations with Pietrain sire lines show better body width and carcass leanness mid shorter body length.

Key words: hybrid young pig stock; live weight; growth; conformation; adaptation. 